\title{
Assessment of role perception and job performance of ASHAs in Vijyapaura district, Karnataka
}

\author{
Rohith $\mathbf{M}^{1^{*}}$, M. M. Angadi \\ ${ }^{\mathbf{1}}$ Assistant Professor, ${ }^{2}$ Professor and HOD, Dept. of Community Medicine, ${ }^{\mathbf{1}}$ Yenepoya Medical College, Mangalore, Karnataka, ${ }^{\mathbf{2}}$ Shridevi \\ Institute of Medical Sciences and Research Hospital, Tumkur, Karnataka, India \\ *Corresponding Author: Rohith M \\ Email: drrohith88@gmail.com
}

\begin{abstract}
Introduction: ASHAs play an important role in the rollout of government health programmes such as the Janani Suraksha Yojana (JSY), a conditional cash transfer scheme to incentivise women to give birth in a health facility. The ASHAs work closely with other frontline workers like Auxiliary Nurse Midwives (ANMs) and Anganawadi Workers (AWWs) to conduct community-level activities. ASHAs also act as health activists in the community who will create awareness on health and its determinants, counsel mothers on key healthy behaviours and mobilise the community towards local health planning and increased utilisation and accountability of the existing health services.

Objectives: To evaluate the Role perception and Job Performance of ASHAs.

Materials and Methods: A cross sectional study was done on 617 ASHAs. A pre-designed, semi- structured schedule was prepared in accordance with the study objectives. The questionnaire was prepared in English and the interview was conducted in Kannada language by explaining them questions one by one. Data collection was done by interview technique.

Results: 603 (97.7\%) of ASHAs had positive attitude towards mobilising the community for accessing health services such as ANC, 602 (97.5\%) for ANC, 599(97.08\%) for institutional delivery, 597 (96.7\%) for birth preparedness, 601(97.4\%) for new born care, 600(97.2\%) towards exclusive breast feeding. $405(65.6 \%)$ ASHAs told that they are actively involved in distributing Iron and Folic acid tablets to pregnant women. 597 (96.7\%) ASHAs informed that they educate mothers about exclusive breast feeding, while 471(76.3\%) told that they encourage mothers to continue breast feeding when the child is suffering from diarrhoea.

It was found that job performance of ASHAs was significantly associated with Age, Days of Training and Duration of service of ASHAs. Conclusion: In order to orient the ASHAs on their job profile and responsibility, there is a need to assess the knowledge and skills of Accredited Social Health Activists (ASHA) on issues relating to maternal and child health and nutrition, and also perception of their role with respect to ICDS related activities, for bringing about corrective actions.
\end{abstract}

Keywords: ASHA, Role Perception, Job performance.

\section{Introduction}

The Government of India's flagship National Rural Health Mission (NRHM) aims to provide accessible, affordable and effective primary health care, especially to poor and vulnerable sections of the population and to address the deficit in rural health care. ${ }^{1}$ NRHM has created a cadre of trained female community health activists called Accredited Social Health Activists (ASHAs) to mobilise the community toward increased utilisation of existing health services. ${ }^{2}$

ASHAs are selected from the village itself (one for 1000 population), preferably in the age group of 25-45 years with minimum formal education of 8 years. NRHM has envisaged capacity building of ASHAs through training, and for motivating them, there is a provision of performance-based incentive system. They are trained to provide primary medical care, health education on sanitation, hygiene, antenatal care (ANC) and postnatal care (PNC), escorting expectant mothers to the hospital for safe delivery, and immunization of children, etc. ASHAs responsibilities range from health education to detection of diseased cases and referral to higher health facilities. ${ }^{3}$

ASHAs play an important role in the rollout of government health programmes such as the Janani Suraksha Yojana (JSY), a conditional cash transfer scheme to incentivise women to give birth in a health facility. The ASHAs work closely with other frontline workers like
Auxiliary Nurse Midwives (ANMs) and Anganawadi Workers (AWWs) to conduct community-level activities. ${ }^{4}$

ASHAs also act as health activists in the community who will create awareness on health and its determinants, counsel mothers on key healthy behaviours and mobilise the community towards local health planning and increased utilisation and accountability of the existing health services. ${ }^{5}$

Previous studies on ASHA workers in India have shown that majority of ASHAs (73-78\%) were either middle or high school passed, which shows selection is in adherence with selection criteria of ASHAs ${ }^{6,7}$. Several ASHAs (69-72\%) were unable to specify all their job responsibilities. Many ASHA's (81-93\%) claimed that they work approximately 25 hours a week. ${ }^{8,9}$ It was found that huge percentages of ASHAs (91-95.5\%) were serving for the population which was more than 1000 in number. Also, majority of the ASHAs $(74.65 \%)$ received only 12 days of training against the recommended 23 days of training. ${ }^{10}$

\section{Roles and Responsibilities of $\mathrm{ASHA}^{\mathbf{1 - 5}}$}

The roles and responsibilities of ASHA are as follows:

1. ASHA will be the first port of call for any health related demands

2. ASHA will take steps to create awareness and provide information to the community on social determinants of health. 
3. ASHA will mobilise the community and facilitate them in accessing health and health related services available at the village/sub-centre/primary health centres.

4. She will work with the "Village Health, Sanitation and Nutrition Committee" (VHSNC) of the Gram Panchayat to develop a comprehensive village health plan.

5. ASHA will provide primary medical care for minor ailments such as diarrhoea, fever, and first aid for minor injuries.

6. ASHAs would reinforce community action for institutional delivery, universal immunization, newborn care, prevention of communicable diseases

7. She will also help the villagers in adopting promotive and preventive health by educating them on nutrition, drinking water, sanitation and utilization of health services

8. She will promote construction of household toilets under Total Sanitation Campaign among villagers.

The implementation of ASHA programme was started in 2005 in Karnataka state and it was implemented in 2008 in Vijayapur district. ${ }^{3}$

Out of 1410 ASHA posts sanctioned for Vijayapur district, 1394 have been filled. All of the appointees have undergone training. During our study period, 1093 ASHA's were working. This study was done for a period of 11 months to assess Knowledge, Attitude, and Practice of ASHAs in delivering the health care services.

\section{Aims and Objectives}

1. To describe the socio-demographic profile of ASHAs working in Vijayapur district.

2. To evaluate the Role perception and Job Performance of ASHAs.

\section{Materials and Methods}

The current study was carried out in Karnataka state, India.

\section{Study design}

Cross sectional study.

\section{Study area}

Vijayapur district.

Total study period

11 months.

\section{Study subjects}

All the ASHAs of 3 taluks' (Vijayapur, Basavana Bagewadi and Muddebihal) of Vijayapur district.

\section{Inclusion criteria}

1. All the ASHAs working for more than 6 months

2. ASHAs who have undergone training

\section{Exclusion criteria}

1. Newly recruited ASHA's (<6 months)

2. ASHA's who do not give their consent.

Official permission was obtained from District Heath Officer, Vijayapur. Details of ASHA's working in the above three taluks were obtained from District Health Office, Vijayapur. Along with that, information of ASHA facilitator and the details of all the Medical Officers and their PHC's of the study area were obtained. 248 ASHA's are working under 15 PHC's in Vijayapur taluk, 223 ASHA's are working under 14 PHC's in Basavana Bagewadi taluk and 186 ASHAs are working under 10PHCs in Muddebihal taluk. So, a total of 617 ASHA's were included in the study.

A pre-designed, semi- structured schedule was prepared in accordance with the study objectives. The schedule was prepared in English and the interview was conducted in Kannada language by explaining them questions one by one.

A pre-set date was designated with the prior permission of the Medical Officer. After obtaining his/her permission, ASHA facilitator was informed to mobilise the ASHAs from nearby 4-5 surrounding PHCs to a PHC which was decided as the centre for data collection. A preliminary selfintroduction to every subject, orientation about the study, purpose of the study and manner in which it will be carried out was explained to them.

Data collection was done by interview technique. It included a schedule based oral interview. The interview was conducted by the investigator after taking oral consent of the study subjects at the PHC. Face to face interviews was carried out in Kannada, explaining them each question in detail and making sure they understand every bit of it. Once, all the ASHAs finished the question, and then the next question was taken up in the interview.

All responses were tabulated by the investigator using Microsoft Excel 2007 software. Graphical representations were made wherever necessary. Data was analysed by using SPSS software version 21. Statistical used are Mean, Proportions and percentages and Chi- square test.

\section{Results}

Table 1: Represents socio-demographic profile of ASHAs who were studied

\begin{tabular}{|l|c|c|c|}
\hline \multirow{2}{*}{$\begin{array}{l}\text { Age profile of ASHAs } \\
\text { Mean age- 30.67 }\end{array}$ S.D: $\mathbf{4 . 6 5}$} & & Frequency & Percent \\
\cline { 2 - 4 } & $20-29$ & 290 & $47.0 \%$ \\
\cline { 2 - 4 } & $30-39$ & 323 & $52.4 \%$ \\
\cline { 2 - 4 } & $40-49$ & 4 & $0.6 \%$ \\
\hline \multirow{3}{*}{ Marital status of ASHAs } & Married & 423 & $68.6 \%$ \\
\cline { 2 - 4 } & Widowed & 116 & $12.3 \%$ \\
\hline Educational status & Separated & 534 & $86.1 \%$ \\
\hline
\end{tabular}




\begin{tabular}{|l|c|c|c|}
\hline \multirow{3}{*}{ Religion } & College & 83 & $13.5 \%$ \\
\hline \multirow{3}{*}{ Monthly income } & Hindu & 591 & $95.8 \%$ \\
\cline { 2 - 4 } & Muslim & 18 & $2.9 \%$ \\
\cline { 2 - 4 } & Others & 8 & $1.3 \%$ \\
\hline \multirow{3}{*}{ Husbands occupation } & $<5000$ & 459 & $74.4 \%$ \\
\cline { 2 - 4 } & $\approx 5000.00$ & 107 & $17.3 \%$ \\
\hline \multirow{2}{*}{ Family type } & $>5000$ & 51 & $8.3 \%$ \\
\hline \multirow{2}{*}{ Does the ASHA work for same village } & Farmer & 308 & $72.8 \%$ \\
\hline \multirow{2}{*}{ Duration of service } & Daily wage worker & 73 & $17.2 \%$ \\
\cline { 2 - 4 } & Unemployed & 42 & $10 \%$ \\
\cline { 2 - 4 } & Nuclear & 135 & $78.1 \%$ \\
\cline { 2 - 4 } & Joint & 494 & $21.9 \%$ \\
\cline { 2 - 4 } & Yes & 123 & $19.1 \%$ \\
\cline { 2 - 4 } & No & 257 & $41.6 \%$ \\
\hline
\end{tabular}

Table 2: Shows Role perception (Attitude) of ASHAs. It includes positive responses (i.e. YES) which ASHAs gave.

\begin{tabular}{|l|c|c|}
\hline Perceptions by ASHAs & $\begin{array}{c}\text { Total } \\
(\%)\end{array}$ & $\begin{array}{c}\text { Percentage } \\
(\%)\end{array}$ \\
\hline Is it Necessary to provide information about existing health services? & 617 & $100 \%$ \\
\hline Is it necessary to create awareness on health, hygiene and nutrition? & 617 & $100 \%$ \\
\hline Is it required to mobilise the community for accessing health services such as & \multicolumn{2}{|l|}{} \\
\hline ANC & 603 & $97.7 \%$ \\
\hline PNC & 602 & $97.5 \%$ \\
\hline Instuitional delivery & 599 & $97.08 \%$ \\
\hline Illness/ Fever & 597 & $96.7 \%$ \\
\hline Birth preparedness & 597 & $96.7 \%$ \\
\hline New born care & 601 & $97.4 \%$ \\
\hline Exclusive Breast Feeding & 600 & $97.2 \%$ \\
\hline Immunization of mother & 596 & $96.5 \%$ \\
\hline Immunization of infants & 602 & $97.5 \%$ \\
\hline Use of Family Planning methods & 599 & $97.08 \%$ \\
\hline
\end{tabular}

Table 3: Represents the major activities carried out by ASHAs in their field practice area

\begin{tabular}{|c|c|c|c|c|c|c|c|c|c|c|}
\hline \multirow{2}{*}{$\begin{array}{l}\text { Variables } \\
(n=617)\end{array}$} & \multicolumn{3}{|c|}{ Age $(\%)$} & \multicolumn{2}{|c|}{$\begin{array}{l}\text { Days of } \\
\text { Training } \\
(\%)\end{array}$} & \multicolumn{2}{|c|}{$\begin{array}{l}\text { Education } \\
\quad(\%)\end{array}$} & \multicolumn{2}{|c|}{$\begin{array}{l}\text { Duration of } \\
\text { Service }(\%)\end{array}$} & \multirow{2}{*}{$\begin{array}{c}\text { Total } \\
(\%)\end{array}$} \\
\hline & $20-29$ & $30-39$ & $40-49$ & $\begin{array}{c}17 \\
\text { Days }\end{array}$ & $\begin{array}{c}23 \\
\text { Days }\end{array}$ & $\begin{array}{l}\text { High } \\
\text { School }\end{array}$ & College & $\begin{array}{l}<5 \\
\text { yrs }\end{array}$ & $\begin{array}{l}>5 \\
\text { yrs }\end{array}$ & \\
\hline ASHAs who serve population $\leq 1000$ & $\begin{array}{l}145 \\
(45.7)\end{array}$ & $\begin{array}{c}169 \\
(53.3) \\
\end{array}$ & $\begin{array}{c}3 \\
(0.94) \\
\end{array}$ & $\begin{array}{c}43 \\
(13.5) \\
\end{array}$ & $\begin{array}{c}274 \\
(86.4)\end{array}$ & $\begin{array}{c}246 \\
(77.6) \\
\end{array}$ & $\begin{array}{c}71 \\
(22.3) \\
\end{array}$ & $\begin{array}{c}121 \\
(38.1) \\
\end{array}$ & $\begin{array}{r}196 \\
(61.9) \\
\end{array}$ & $\begin{array}{r}317 \\
(51.3) \\
\end{array}$ \\
\hline $\begin{array}{l}\text { ASHAs who work a minimum of } 10 \\
\text { hours per week }\end{array}$ & $\begin{array}{l}137 \\
(48.2)\end{array}$ & & $\begin{array}{c}2 \\
(0.7)\end{array}$ & $\begin{array}{c}36 \\
(12.6)\end{array}$ & $\begin{array}{c}248 \\
(87.3)\end{array}$ & $\begin{array}{c}254 \\
(89.4)\end{array}$ & $\begin{array}{c}30 \\
(10.5)\end{array}$ & $\begin{array}{l}111 \\
(39)\end{array}$ & $\begin{array}{l}173 \\
(61)\end{array}$ & $\begin{array}{l}284 \\
(46)\end{array}$ \\
\hline $\begin{array}{l}\text { ASHAs who distribute Iron and Folic } \\
\text { acid tablets to pregnant women? }\end{array}$ & $\begin{array}{c}171 \\
(42.2)\end{array}$ & $\begin{array}{c}233 \\
(57.5)\end{array}$ & $\begin{array}{c}1 \\
(0.2)\end{array}$ & $\begin{array}{c}29 \\
(7.1)\end{array}$ & $\begin{array}{c}376 \\
(92.8)\end{array}$ & $\begin{array}{c}357 \\
88.1)\end{array}$ & $\begin{array}{c}48 \\
(11.8)\end{array}$ & $\begin{array}{c}177 \\
(43.7)\end{array}$ & $\begin{array}{c}228 \\
(56.3)\end{array}$ & $\begin{array}{c}405 \\
(65.6)\end{array}$ \\
\hline $\begin{array}{l}\text { ASHAs who educate mothers about } \\
\text { Exclusive Breast Feeding? }\end{array}$ & $\begin{array}{l}280 \\
(47) \\
\end{array}$ & $\begin{array}{c}313 \\
52.4) \\
\end{array}$ & $\begin{array}{c}4 \\
(0.67) \\
\end{array}$ & $\begin{array}{c}76 \\
(12.7) \\
\end{array}$ & $\begin{array}{c}521 \\
(87.2) \\
\end{array}$ & $\begin{array}{c}524 \\
(87.7) \\
\end{array}$ & $\begin{array}{c}73 \\
(12.2) \\
\end{array}$ & $\begin{array}{c}219 \\
(36.6) \\
\end{array}$ & $\begin{array}{c}378 \\
(63.4) \\
\end{array}$ & $\begin{array}{c}597 \\
(96.7) \\
\end{array}$ \\
\hline $\begin{array}{l}\text { ASHAs who encourage mothers to } \\
\text { breast feed during diarrhoea }\end{array}$ & $\begin{array}{l}221 \\
(47) \\
\end{array}$ & $\begin{array}{c}247 \\
(52.4) \\
\end{array}$ & $\begin{array}{c}3 \\
(0.63) \\
\end{array}$ & $\begin{array}{c}63 \\
(13.3) \\
\end{array}$ & $\begin{array}{c}408 \\
(86.6) \\
\end{array}$ & $\begin{array}{c}399 \\
(84.7) \\
\end{array}$ & $\begin{array}{c}72 \\
(15.2) \\
\end{array}$ & $\begin{array}{c}199 \\
(42.2) \\
\end{array}$ & $\begin{array}{c}272 \\
(57.3) \\
\end{array}$ & $\begin{array}{c}471 \\
(76.3) \\
\end{array}$ \\
\hline $\begin{array}{l}\text { ASHAs who assist ANM } \\
\text { immunisation days? }\end{array}$ & $\begin{array}{c}253 \\
(47.2)\end{array}$ & $\begin{array}{l}278 \\
(52)\end{array}$ & $\begin{array}{c}4 \\
(0.7)\end{array}$ & $\begin{array}{c}72 \\
(13.4)\end{array}$ & $\begin{array}{c}463 \\
(86.5)\end{array}$ & $\begin{array}{c}459 \\
(85.7)\end{array}$ & $\begin{array}{c}76 \\
(14.2)\end{array}$ & $\begin{array}{c}201 \\
(37.5)\end{array}$ & $\begin{array}{c}334 \\
(62.5)\end{array}$ & $\begin{array}{c}535 \\
(86.7)\end{array}$ \\
\hline ASHAs who work as DOTS agent? & $\begin{array}{c}39 \\
(38.6)\end{array}$ & $\begin{array}{r}62 \\
(61.3) \\
\end{array}$ & $\begin{array}{c}0 \\
(00)\end{array}$ & $\begin{array}{c}11 \\
(10.8)\end{array}$ & $\begin{array}{c}90 \\
(89.1)\end{array}$ & $\begin{array}{c}94 \\
(93)\end{array}$ & $\begin{array}{c}7 \\
(7) \\
\end{array}$ & $\begin{array}{c}35 \\
(34.6)\end{array}$ & $\begin{array}{c}66 \\
(65.4) \\
\end{array}$ & $\begin{array}{c}101 \\
(16.3) \\
\end{array}$ \\
\hline $\begin{array}{lllll}\begin{array}{l}\text { ASHAs who assist } \\
\text { mobilisation? }\end{array} & & & \text { in } \\
\end{array}$ & $\begin{array}{c}269 \\
(47.3) \\
\end{array}$ & $\begin{array}{l}295 \\
(52) \\
\end{array}$ & $\begin{array}{c}4 \\
(0.7) \\
\end{array}$ & $\begin{array}{c}76 \\
13.3) \\
\end{array}$ & $\begin{array}{c}492 \\
(86.6) \\
\end{array}$ & $\begin{array}{c}485 \\
(85.3) \\
\end{array}$ & $\begin{array}{c}83 \\
(14.6) \\
\end{array}$ & $\begin{array}{c}191 \\
(33.6) \\
\end{array}$ & $\begin{array}{c}377 \\
(66.4) \\
\end{array}$ & $\begin{array}{l}568 \\
(92) \\
\end{array}$ \\
\hline $\begin{array}{l}\text { ASHAs who provide information } \\
\text { about birth/death in their village to } \\
\text { PHC/SC }\end{array}$ & $\begin{array}{l}284 \\
(47)\end{array}$ & $\begin{array}{c}316 \\
(52.3)\end{array}$ & $\begin{array}{c}4 \\
(0.66)\end{array}$ & $\begin{array}{c}84 \\
(14)\end{array}$ & $\begin{array}{l}520 \\
(86)\end{array}$ & $\begin{array}{c}521 \\
(86.2)\end{array}$ & $\begin{array}{c}83 \\
(13.7)\end{array}$ & $\begin{array}{c}213 \\
(35.2)\end{array}$ & $\begin{array}{c}391 \\
(64.8)\end{array}$ & $\begin{array}{c}604 \\
(97.8)\end{array}$ \\
\hline
\end{tabular}




\begin{tabular}{|c|c|c|c|c|c|c|c|c|c|c|}
\hline $\begin{array}{l}\text { ASHAs who are actively involved } \\
\text { with PRI/VHSNC in their village? }\end{array}$ & $\begin{array}{c}271 \\
(47.8) \\
\end{array}$ & $\begin{array}{c}291 \\
(51.4) \\
\end{array}$ & $\begin{array}{c}4 \\
(0.7) \\
\end{array}$ & $\begin{array}{c}77 \\
(13.6) \\
\end{array}$ & $\begin{array}{r}489 \\
(86.3) \\
\end{array}$ & $\begin{array}{c}507 \\
(89.5) \\
\end{array}$ & $\begin{array}{c}59 \\
(10.4) \\
\end{array}$ & $\begin{array}{c}205 \\
(36.2) \\
\end{array}$ & $\begin{array}{c}361 \\
(63.8) \\
\end{array}$ & $\begin{array}{c}566 \\
(91.7) \\
\end{array}$ \\
\hline & \multicolumn{3}{|c|}{$\begin{array}{c}x^{2}=9.987 \\
\text { df }=18 \\
p=<0.05\end{array}$} & \multicolumn{2}{|c|}{$\begin{array}{c}x^{2}=1.881 \\
\text { df }=9 \\
p=<0.05\end{array}$} & \multicolumn{2}{|c|}{$\begin{array}{c}\chi^{2}=3.228 \\
\mathrm{df}=9 \\
\mathrm{p}=>0.05\end{array}$} & \multicolumn{2}{|c|}{$\begin{array}{c}x^{2}=11.431 \\
\mathrm{df}=9 \\
\mathrm{p}=<0.05\end{array}$} & \\
\hline
\end{tabular}

It was found that job performance of ASHAs was significantly associated with Age, Days of Training and Duration of service of ASHAs

\section{Discussion}

The present study was carried out with the objective to study Role perception and Job Performance of ASHAs of Vijayapur district along with description of their sociodemographic profile.

In our current study on 617 ASHAs, all the ASHAs felt it is necessary to provide information about existing health services and it is necessary to create awareness on health, hygiene and nutrition in the community. This was similar to the study conducted by Desai PB et al., ${ }^{6}$ and Saurabh R Shrivastava et al. ${ }^{7}$

Majority of ASHAs had a positive attitude towards their roles and responsibilities regarding ANC, PNC, Institutional delivery, Birth Preparedness, Exclusive Breast Feeding, New Born Care, Immunization of Mother and Infants and use of Family Planning. Similar results have been obtained by multi-state survey by National Institute of Public Cooperation and Child Development ${ }^{24}$ also studies by Mrigen Deka et al., ${ }^{8}$ Charu Kohli et al., ${ }^{9}$ and Shrivatsa et al., ${ }^{10}$

However, in a study by H R Salve et al., ${ }^{11}$ it was found that $21.3 \%$ of ASHAs had negative and stigmatised attitude towards mental health.

Regarding the ASHAs visit to Anganawadi centre, $40.5 \%$ Of ASHAs told that they visit more than 3 times a month. They also mentioned that they assist AWW (92\%) in maintaining the records of children and pregnant. They also mentioned their help in mobilizing pregnant and lactating women and infants for nutrition supplement. These findings were roughly similar to a study by Dr. Shobha Malini et al., ${ }^{12}$ and Hiader et al., ${ }^{13}$ where $53 \%$ and $59.5 \%$ of ASHAs visited the AWC more than 3 times in a month and assisting AWW in updating the list of eligible couples and also the children less than one year of age in the village.

92\% of ASHAs were well aware of the objectives of Village Health Sanitation Nutrition Committee and were actively involved in it. It is similar to the findings in the study done by KCDS et al., ${ }^{14}$ where awareness about the objectives of the VHSCs was highest among the ASHAs when compared to ANMs. The study also found that ASHAs were well aware about the formation process of VHSNC.

However in a study by Das A et al., ${ }^{15}$ most of the ASHAs $(82.5 \%)$ have indicated that the villages do not have a VHSC. Only $14.5 \%$ of ASHAs have indicated about the existence, out of them only 11 have attended the meeting during the last one month to one week.

$58.9 \%$ of ASHAs told that they received good support from PRI member in regard to community mobilisation and celebration of health days. The results were roughly similar to study Dr. Shobha Malini et al. ${ }^{12}$

\section{Conclusion}

The preliminary finding of the National ASHA Mentoring Group (NAMG) has revealed that there has been confusion in many States among the ASHAs on their own role and also among the AWWs and ANMs on the role of ASHA. In order to orient the ASHAs on their job profile and responsibility, there is a need to assess the knowledge and skills of Accredited Social Health Activists (ASHA) on issues relating to maternal and child health and nutrition, and also perception of their role with respect to ICDS related activities, for bringing about corrective actions.

\section{Source of Funding}

None.

\section{Conflict of Interest}

None.

\section{References}

1. Guidelines on Accredited Social Health Activists (ASHA). India: [Internet] 2009; [Cited 2016/September/10]. Available from

www.mohfw.nic.in/NRHM/RCH/guidelines/ASHA_guidelines

2. Park K. Park's textbook of Preventive and Social Medicine. $22^{\text {nd }}$ ed. Jabalpur: M/s Banarsidas Bhanot; 2011;405-06.

3. National Rural Health Mission (2005-2012): Mission documents and monograph 1-6 Ministry of Health and Family Welfare, Nirman Bhawan, New Delhi: [Internet] 2005;[Cited on 2015/May/12]. Available from:

www.mohfw.nic.in/nrhm.html

4. Update on the ASHA programme: National Rural Health Mission, Ministry of Health and Family Welfare, Govt. of India, New Delhi; Jan-2012.

5. About ASHA - Government of India [Internet] 2016; [cited 13 July 2016]. Available from:

http://nrhm.gov.in/communitisation/asha/about-asha.html.

6. Desai PB. Role of Accredited Social Health Activists (ASHAS) in the Improvement of Health Status of Villagers under NRHM in Kolhapur District, Maharashtra. J Community Med Health Educ. 2016; 6(2):64-8.

7. Shrivastava SR, Shrivastava PS. Evaluation of trained Accredited Social Health Activist (ASHA) workers regarding their knowledge, attitude and practices about child health. Int Electron J Rural Remote Health Res, Educ, Pract Policy. 2012;12(4):43-9.

8. Deka M. A study on evaluation of ASHAs for their knowledge, attitude and practice towards newborn care in RHTC area of district Jhansi in Uttar Pradesh. Int J Health Sci Res. 2014;4(7):43-8.

9. Kohli C, Kishore J, Shantanu S. Knowledge and practice of accredited social health activists for maternal healthcare delivery in Delhi. J Family Med Prim Care. 2015;4(3):359-63. 
10. Srivastava DK, Prakash S, Adhish V, Nair KS, Gupta S, Nandan D. A study of interface of ASHA with the community and the service providers in Eastern Uttar Pradesh. Indian $J$ Public Health. 2009; 53(3):133-6.

11. Salve HR, Babu S, Rai SK, Sagar R. Attitude about mental illness of health care providers and community leaders in Rural Haryana, North India. Indian J Community Health. 2014;26(4):374-8.

12. Malini S, Tripathi RM, Khattar P, Nair KS, Tekhre YL, Dhar N. A rapid appraisal on functioning of Janani Suraksha Yojana in South Orissa. Health Popul: Perspect Issues. 2008;31(2):126-31.

13. Haider S, Adhish V, Gupta S, Dhar N. A rapid appraisal of SAHIYA (ASHA) in Jharkhand. Health and Population: Perspectives and Issues. 2008;31(2):80-4.

14. Kalinga Centre for Social Development (KCDS). Rapid Appraisal of Functioning of Village Health and Sanitation
Committee (VHSCs) under NRHM in Orissa (Sponsored by NIHFW and UNFPA). Bhubaneswar, Orissa. [Internet] 2008; [Cited on 2016/June/19]. Available from: http://nihfw.org/pdf/rahi-i\%20reports/kalinga/kalinga.pdf

15. Das A, Dasgupta A. An Exploratory Analysis of Knowledge and Practice, Job-Related Difficulties and Dissatisfaction of ASHAs in Rural India. Int J Curr Res Rev. 2015;7(10):14-9.

How to cite this article: Rohith M, Angadi MM. Assessment of role perception and job performance of ASHAs in Vijyapaura district, Karnataka. Indian $J$ Forensic Community Med. 2020;7(1):42-6. 